\title{
Vagotomy ameliorates islet morphofunction and body metabolic homeostasis in MSG-obese rats
}

\author{
C. Lubaczeuski $^{1}$, S.L. Balbo ${ }^{1}$, R.A. Ribeiro ${ }^{2}$, J.F. Vettorazzi ${ }^{3}$, J.C. Santos-Silva ${ }^{3}$, \\ E.M. Carneiro ${ }^{3}$ and M.L. Bonfleur ${ }^{1}$ \\ ${ }^{1}$ Laboratório de Fisiologia Endócrina e Metabolismo, Centro de Ciências Biológicas e da Saúde, \\ Universidade Estadual do Oeste do Paraná, Cascavel, PR, Brasil \\ ${ }^{2}$ Universidade Federal do Rio de Janeiro, Macaé, RJ, Brasil \\ ${ }^{3}$ Laboratório de Pâncreas Endócrino e Metabolismo, Departamento de Biologia Estrutural e Funcional, Instituto de Biologia, \\ Universidade Estadual de Campinas, Campinas, SP, Brasil
}

\begin{abstract}
The parasympathetic nervous system is important for $\beta$-cell secretion and mass regulation. Here, we characterized involvement of the vagus nerve in pancreatic $\beta$-cell morphofunctional regulation and body nutrient homeostasis in 90-day-old monosodium glutamate (MSG)-obese rats. Male newborn Wistar rats received MSG (4 g/kg body weight) or saline [control (CTL) group] during the first 5 days of life. At 30 days of age, both groups of rats were submitted to sham-surgery (CTL and MSG groups) or subdiaphragmatic vagotomy (Cvag and Mvag groups). The 90-day-old MSG rats presented obesity, hyperinsulinemia, insulin resistance, and hypertriglyceridemia. Their pancreatic islets hypersecreted insulin in response to glucose but did not increase insulin release upon carbachol (Cch) stimulus, despite a higher intracellular $\mathrm{Ca}^{2+}$ mobilization. Furthermore, while the pancreas weight was $34 \%$ lower in MSG rats, no alteration in islet and $\beta$-cell mass was observed. However, in the MSG pancreas, increases of $51 \%$ and $55 \%$ were observed in the total islet and $\beta$-cell area/pancreas section, respectively. Also, the $\beta$-cell number per $\beta$-cell area was $19 \%$ higher in MSG rat pancreas than in CTL pancreas. Vagotomy prevented obesity, reducing $25 \%$ of body fat stores and ameliorated glucose homeostasis in Mvag rats. Mvag islets demonstrated partially reduced insulin secretion in response to $11.1 \mathrm{mM}$ glucose and presented normalization of Cch-induced $\mathrm{Ca}^{2+}$ mobilization and insulin release. All morphometric parameters were similar among Mvag and CTL rat pancreases. Therefore, the higher insulin release in MSG rats was associated with greater $\beta$-cell/islet numbers and not due to hypertrophy. Vagotomy improved whole body nutrient homeostasis and endocrine pancreatic morphofunction in Mvag rats.
\end{abstract}

Key words: $\beta$-Cell; Obesity; Parasympathetic nervous system

\section{Introduction}

Central and peripheral mechanisms are involved in the regulation of body glucose homeostasis (1). Insulin and glucagon secretion are directly controlled by peripheral glucose levels and by the central nervous system (CNS) through the autonomic nervous system (ANS) (2). Pancreatic islets are innervated by vagal cholinergic nerves and sympathetic fibers (3). The parasympathetic nervous system (PNS) potentiates insulin secretion by the acetylcholine muscarinic 3 (M3) receptor, which activates phospholipase C (PLC) that, in turn, produces the intracellular messengers inositol1,4,5-triphosphate (IP3) and diacylglycerol (DAG) (2). In contrast, the sympathetic nervous system (SNS), which releases norepinephrine, predominantly decreases insulin secretion via the $\alpha 2$-adrenergic receptors (3).
Nutrients and hormones also contribute to pancreatic $\beta$-cell mass steady state, and the PNS has been found to be involved in $\beta$-cell mass regulation under normal and pathological conditions (4-9). While the mechanism of action of the PNS upon endocrine pancreatic mass regulation is not completely understood, there is some evidence to demonstrate that, in obesity, increased vagal action may lead to a vicious cycle that increases fat storage and disrupts body energy homeostasis $(10,11)$.

Early postnatal administration of monosodium glutamate (MSG) in rodents produces neuronal necrosis in the arcuate nuclei of the hypothalamus and median eminence, which leads to development of obesity during adulthood (12). MSG-induced obesity is characterized by hypo- or

Correspondence: M.L. Bonfleur: <mlbonfleur@hotmail.com>.

Received August 28, 2014. Accepted November 17, 2014. First published online February 26, 2015. 
normophagy (13), higher fat deposition, glucose intolerance, hyperinsulinemia, and insulin resistance (14). Furthermore, pancreatic islets from MSG-obese rodents secrete more insulin in response to glucose (15-17) but present a diminished secretory function in response to cholinergic stimulus $(15,18)$. This effect is partly associated with an alteration in ANS action, with a reduction in sympathetic function, but enhanced PNS activity (10). We previously demonstrated that subdiaphragmatic vagotomy in MSG rats prevented obesity, glucose intolerance, and pancreatic islet hypersecretion in response to glucose $(14,16)$, supporting the hypothesis that PNS action is involved in pancreatic islet hyperfunction and related comorbidities in MSG rodents. However, the mechanism of action involved in such a process is unknown. Here, once again using subdiaphragmatic vagal denervation, performed at 30 days of age, we investigated whether the vagus nerve is involved in endocrine pancreatic morphofunctional alterations that lead to hyperinsulinemia and body nutrient homeostasis disruption in 90-day-old MSG-obese rats.

\section{Material and Methods}

\section{Induction of experimental obesity in rats}

All experiments were approved by the Universidade Estadual do Oeste do Paraná (UNIOESTE) Committee on Ethics in Animal Experimentation (Certificate \#00812). Male newborn Wistar rats received a subcutaneous injection of MSG [4 g/kg body weight (BW); MSG group], or saline $(1.25 \mathrm{~g} / \mathrm{kg} \mathrm{BW}$; CTL group) during the first 5 days of life. Pups were weaned on the 21st day of life and had free access to standard rodent chow (Biobase, Brazil) and water. The rats were housed in standard cages and maintained on a 12:12-h light-dark cycle (lights on from 6:00 a.m. to 6:00 p.m.) under controlled temperature $\left(22 \pm 1^{\circ} \mathrm{C}\right)$.

\section{Vagotomy}

At 30 days of age, MSG and CTL rats, after $12 \mathrm{~h}$ of fasting, were anesthetized with a mixture of $90 \mathrm{mg} / \mathrm{kg}$ ip ketamine (Vetbrands, Brazil) and $9 \mathrm{mg} / \mathrm{kg}$ ip xylazine (Vetbrands). Half of the rats were submitted to subdiaphragmatic truncal vagotomy. The stomach and esophagus were exteriorized from the peritoneal cavity and humidified with saline. The common hepatic branch of the ventral vagal trunk, the accessory celiac and gastric branches of the ventral vagal trunk, and the dorsal vagal trunk were cut (denoted as Mvag and Cvag groups) (19). In sham-vagotomized rats (denoted as MSG and CTL groups), the vagus nerve was separated from the esophagus, but was not cut. At the end of the experimental period (2 months later), stomach food retention from each group was evaluated by the stomach weight per BW ratio to confirm subdiaphragmatic vagal denervation $(5,14)$.

\section{Obesity and general nutritional parameters}

Body weight and food intake were measured during the experimental period (from the 30th to 90th day of life). Food intake is reported as feed efficiency (food intake/BW gain). At 90 days of age, both rat groups, after $12 \mathrm{~h}$ of fasting, were weighed, and the nasoanal length was measured to calculate the Lee index. Rats were then killed by decapitation, and the retroperitoneal and perigonadal fat pads were removed and weighed. Blood was collected and serum was stored at $-20^{\circ} \mathrm{C}$ for insulin measurement by radioimmunoassay (RIA). Total cholesterol ( $\mathrm{CHOL})$ and triglycerides (TG) were measured using standard commercial kits, according to the manufacturers' instructions (Merck, Germany; and Boehringer, Germany, respectively).

\section{Intraperitoneal glucose tolerance test (ipGTT)}

At the end of the experimental period, rats from all groups were deprived of food for $8 \mathrm{~h}$, and glycemia (time 0 ) was measured using a glucose analyzer (Abbott, Optium Xceed, USA). Subsequently, the rats received an ip injection of $2 \mathrm{~g} / \mathrm{kg}$ BW glucose, and blood samples were collected at 15, 30, 60 and $120 \mathrm{~min}$. Additional blood samples were collected at 0 and 30 min of the test for insulin measurement by RIA.

\section{Body insulin sensitivity}

Tissue insulin sensitivity was also evaluated using the homeostasis model assessment (HOMA) index of insulin resistance $[($ HOMA-IR) $=$ fasting insulin $(1 \mathrm{U} / \mathrm{mL}) \times$ fasting glucose $(\mathrm{mM}) / 22.5]$. For glucose disappearance rate $\left(\mathrm{K}_{\mathrm{ITT}}\right)$ evaluation, fasted rats were injected ip with $1 \mathrm{U} / \mathrm{kg}$ BW of human insulin (Humulin R, Lilly, USA). Blood was taken before insulin injection (time 0) and after 4, 8, 12, 16 and 20 min for glucose analysis. The $\mathrm{K}_{\mathrm{ITT}}$ was calculated as $0.693 / t_{1 / 2}$.

\section{Lipids, TG, and CHOL content in the liver}

Liver lipids were extracted by Folch's method. The extract was evaporated and weighed by a gravimetric method for total fat content measurement. Lipids were then diluted in isopropanol for determination of the TG and $\mathrm{CHOL}$ content in the liver using enzymatic colorimetric methods, according to the manufacturer's instructions (Laborclin, Bioliquid, Brazil).

\section{Islet isolation, static insulin secretion, and total islet insulin content}

Islets were isolated by collagenase (Sigma-Aldrich Chemicals, USA) digestion of the exocrine pancreas and then selection under a microscope to exclude any contaminating tissues. For static incubations, groups of four islets were preincubated for $30 \mathrm{~min}$ at $37^{\circ} \mathrm{C}$ with $0.5 \mathrm{~mL}$ Krebsbicarbonate (KBR) buffer with the following composition: $115 \mathrm{mM} \mathrm{NaCl}, 5 \mathrm{mM} \mathrm{KCl}, 2.56 \mathrm{mM} \mathrm{CaCl}_{2}, 1 \mathrm{mM} \mathrm{MgCl}_{2}$, $10 \mathrm{mM} \mathrm{NaHCO} 3,15 \mathrm{mM}$ HEPES, supplemented with $5.6 \mathrm{mM}$ glucose, $3 \mathrm{~g}$ bovine serum albumin (BSA) per liter, and equilibrated with a mixture of $95 \% \quad \mathrm{O}_{2}-5 \% \quad \mathrm{CO}_{2}$ to provide $\mathrm{pH}$ 7.4. This medium was then replaced with fresh 
buffer (1 mL), and the islets were incubated for $1 \mathrm{~h}$ with 2.8 , 11.1 or $16.7 \mathrm{mM}$ glucose. In another series of experiments, islets were incubated with $11.1 \mathrm{mM}$ glucose without or with $100 \mu \mathrm{M}$ carbachol (Cch). At the end of the incubation period, the supernatants were collected and maintained at $-20^{\circ} \mathrm{C}$. For islet insulin content, groups of four islets were collected and transferred to tubes containing $1 \mathrm{~mL}$ deionized water, and the islet cells were homogenized using a sonicator (Brinkmann Instruments, USA). The insulin was measured by RIA using human insulin radiolabelled with ${ }^{125} \mathrm{I}$ as tracer, rat insulin as standard (Crystal Chem Inc., USA), and rat insulin antibody (donated by Dr LeclerqMeyer, Free University of Brussels, Belgium). The charcoaldextran method was used to separate free insulin from antibody-bound ${ }^{125}$ I insulin (20).

\section{Cytoplasmic $\mathrm{Ca}^{2+}$ oscillations}

Fresh pancreatic islets were incubated with $5 \mu \mathrm{M}$ fura-2 acetoxymethyl ester for $1 \mathrm{~h}$ at $37^{\circ} \mathrm{C}$ in KBR buffer supplemented with $5.6 \mathrm{mM}$ glucose, $3 \mathrm{~g} \mathrm{BSA} / \mathrm{L}$, at $\mathrm{pH}$ 7.4. The islets were then washed with the same medium and were placed in a chamber that was thermostatically regulated at $37^{\circ} \mathrm{C}$ on the stage of an inverted epifluorescence microscope (Nikon Eclipse TE200, Japan). Islets were then perifused with albumin-free KBR buffer containing 2.8 or $16.7 \mathrm{mM}$ glucose, which was continuously gassed with $95 \%$ $\mathrm{O}_{2}-5 \% \mathrm{CO}_{2}, \mathrm{pH} 7.4$. In another series of experiments, islets were perifused with $\mathrm{Ca}^{2+}$-free $\mathrm{KBR}$ containing $11.1 \mathrm{mM}$ glucose plus $250 \mu \mathrm{M}$ diazoxide and $10 \mathrm{mM}$ EGTA without or with $100 \mu \mathrm{M}$ Cch, as indicated in the legends to Figures 1-6. $A$ ratio image was acquired every $3 \mathrm{~s}$ with a Cool One camera (Photon Technology International, USA) using a dual filter wheel equipped with 340,380 , and $10 \mathrm{~nm}$ bandpass filters, and a range of neutral density filters (Photon Technology International). Data were acquired by using the Image Master version 5.0 (Photon Technology International).

\section{Pancreas morphometry and immunohistochemistry}

For morphometric analysis, pancreases from all groups of rats were removed, weighed, and fixed for $24 \mathrm{~h}$ in Bouin's solution, before embedding in paraffin. From each pancreas, five consecutive $7-\mu \mathrm{m}$ serial sections were selected; a space of $140 \mu \mathrm{m}$ in thickness was then retained, after five more consecutive sections were obtained. Three sections were randomly selected for insulin and one section for glucagon immunoperoxidase reaction. For immunohistochemistry, paraffin was removed; the sections were rehydrated and washed with $0.05 \mathrm{M}$ Tris-saline buffer (TBS), $\mathrm{pH} 7.4$, and subsequently incubated with TBS containing $0.3 \% \mathrm{H}_{2} \mathrm{O}_{2}$ for $30 \mathrm{~min}$ to endogenous peroxidase activity blockade. They were then permeabilized for a further $1 \mathrm{~h}$ with $0.1 \%$ Tween 20 and $5 \%$ of fat-free milk in TBS. Afterwards, the sections were incubated with a polyclonal guinea pig anti-insulin (1:150; Dako North America, Inc., USA) or rabbit antiglucagon (1:50; Dako North America, Inc.) antibody at $4{ }^{\circ} \mathrm{C}$ overnight and, after this period, incubated with rabbit
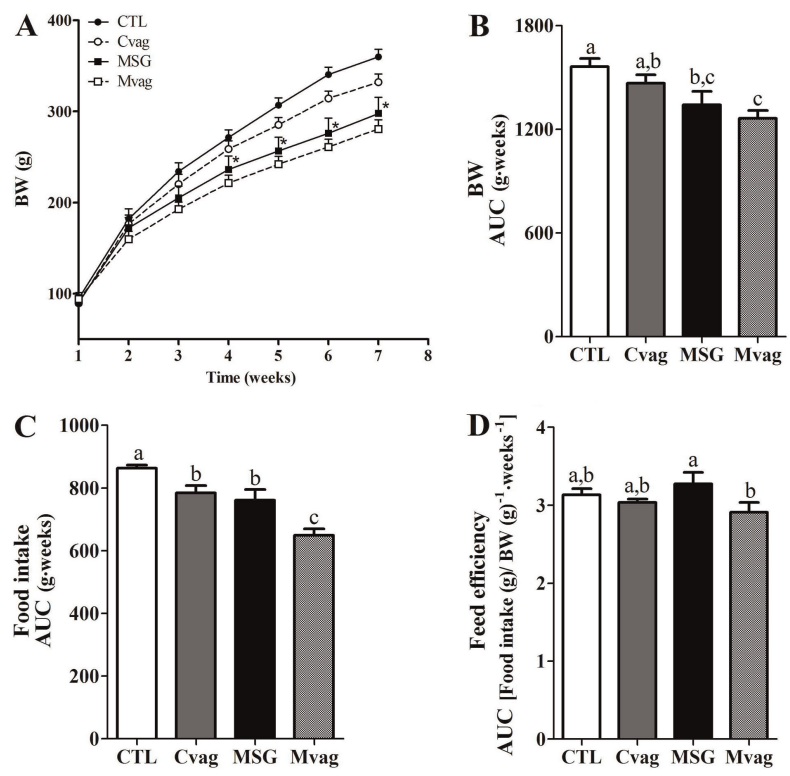

Figure 1. Body weight $(A)$ of CTL, Cvag, MSG and Mvag rats recorded over 6 weeks $(n=6)$. Means \pm SE of the total BW $(B)$ reported as the area under growth curve (AUC), food consumption $(C)$ and food efficiency $(D)$. BW: body weight; CTL: control; Cvag: CTL with subdiaphragmatic vagotomy; MSG: monosodium glutamate; Mvag: MSG with subdiaphragmatic vagotomy. *MSG and Mvag were significantly different from controls. Different letters indicate statistically significant differences (two-way ANOVA followed by Duncan's post-test, $\mathrm{P} \leq 0.05$ ).

anti-guinea pig or goat anti-rabbit conjugated antibody with horseradish peroxidase for $1 \mathrm{~h}$ and $30 \mathrm{~min}$. The positive insulin or glucagon cells were detected with diaminobenzidine (DAB; Sigma-Aldrich Chemicals) solution (10\% DAB and $0.2 \% \mathrm{H}_{2} \mathrm{O}_{2}$ in TBS). Finally, the sections were stained with Ehrlich's hematoxylin and mounted for microscopy. All islets present in the sections were systematically captured with a digital camera coupled to a microscope (Olympus DP71; Olympus BX60; Olympus, Japan).

Islet, $\beta$-cell, and $\alpha$-cell areas were measured using the Image-Pro-Plus Media, Cybernetics Program (USA), and at least 750 islets per group from three to four rats were sampled. The percentages of total islet and $\beta$-cell areas were calculated by dividing the sum of the islet and $\beta$-cell areas, respectively, per pancreas area section and multiplying by $100(21,22)$. The percentages of small, medium, and large islets were calculated as previously reported (21). The islet and $\beta$-cell masses were calculated by multiplying the pancreas weight by the percentage of the total islet and $\beta$ cells areas, respectively $(22,23)$. The $\beta$-cell number was quantified by counting the number of cellular nuclei within the insulin immunoreactive area, and then the results were expressed as $\beta$-cell number per $1000 \mu \mathrm{m}^{2}$ of $\beta$-cell area. The $\beta$-cell size was measured using the same material used for determination of $\beta$-cell area, and was calculated by dividing 

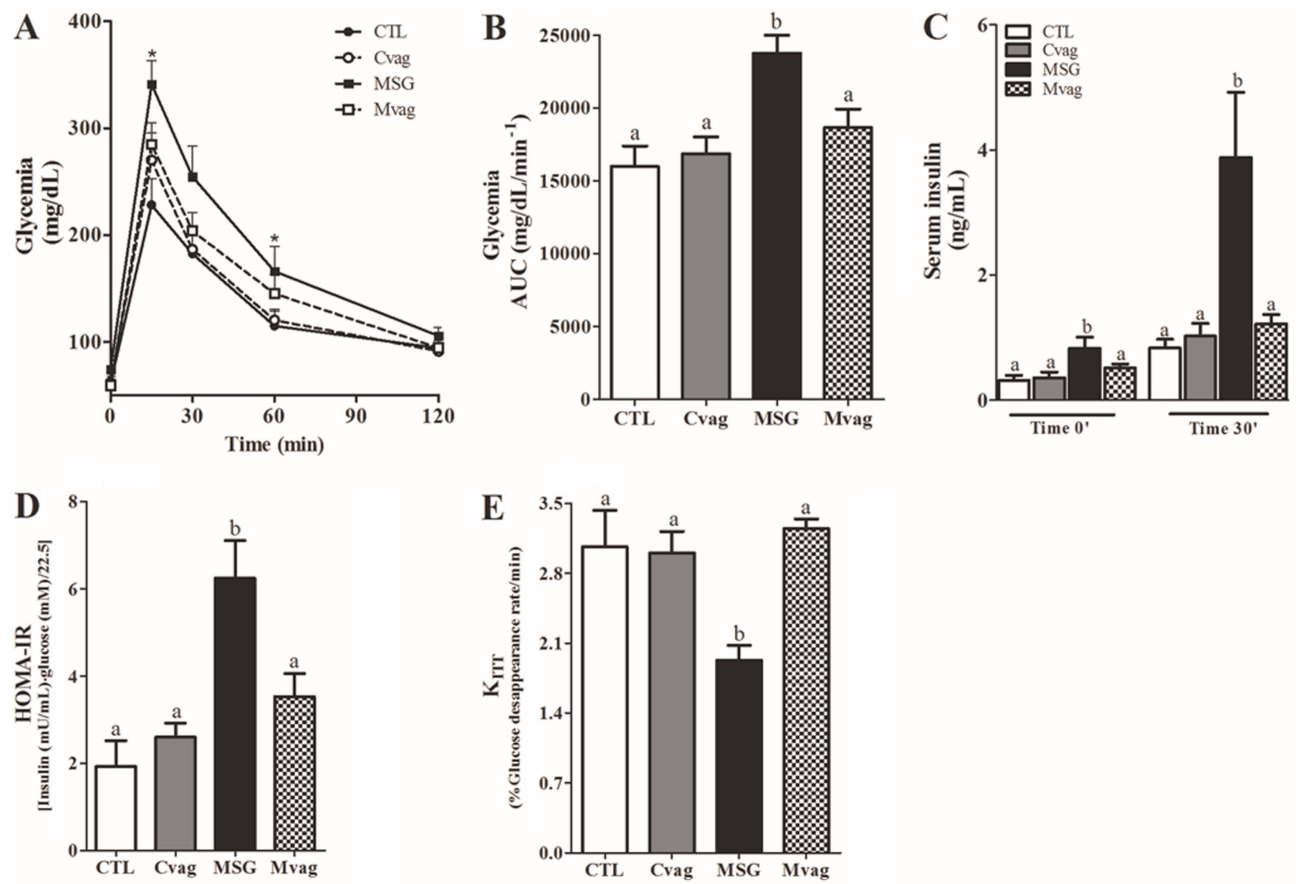

Figure 2. $A$, Changes in blood glucose during the intraperitoneal glucose tolerance test (ipGTT) in 90-day-old CTL, Cvag, MSG and Mvag rats. $B$, Total plasma glucose concentrations during the ipGTT, reported as the AUC. $C$, Insulinemia at 0 and 30 min of the ipGTT. Insulin sensitivity measured by HOMA-IR $(D)$ and $\mathrm{K}_{\mathrm{ITT}}(E)$. CTL: control; Cvag: CTL with subdiaphragmatic vagotomy; MSG: monosodium glutamate; Mvag: MSG with subdiaphragmatic vagotomy; AUC: area under the curve; HOMA-IR: homeostasis model assessment index; $\mathrm{K}_{\mathrm{ITT}}$ : glucose disappearance rate. Data are reported as means $\pm \mathrm{SE}$ obtained from 8 rats for each group. *Significant difference between MSG and CTL. Different letters indicate statistically significant differences (two-way ANOVA followed by Duncan's post-test, $\mathrm{P} \leq 0.05$ ).

$\beta$-cell area per $\beta$-cell number in the insulin immunoreactive area (24).

\section{Statistical analysis}

Results are reported as means \pm SE for the number of determinations $(n)$ indicated. The statistical analyses were carried out using two-way analysis of variance (ANOVA) followed by the Duncan's post-test or Student's $t$-test $(\mathrm{P} \leq 0.05)$ with the Statistica 7.0 software (StatSoft, USA).

\section{Results}

\section{General rat parameters}

Figure $1 \mathrm{~A}$ shows that BW progression in MSG-treated rats was significantly lower at 4 weeks after sham surgery, compared to CTL $(P<0.003)$. The total $B W$, as judged by the area under the growth curve (AUC), was lower in MSG rats than in $C T L$ rats $(P<0.02$; Figure $1 B)$. In addition, the amount of food consumed during the experimental period by MSG rats was lower than that of CTL rats $(P<0.005$; Figure 1C). However, the conversion of this food into efficient BW gain in MSG rats was similar to that seen in CTL rats (Figure 1D). Vagotomy did not modify BW between the groups, whereas it significantly reduced the total food intake in the Cvag and Mvag groups, compared to their respective controls $(P<0.02$ and $P<0.001$, respectively; Figure $1 C)$, and altered feeding efficiency in Mvag in comparison with MSG rats $(P<0.03$; Figure 1D).

At the end of the experimental period, MSG rats showed a reduction of 14 and $8 \%$ in final $\mathrm{BW}$ and nasoanal length, respectively, compared to CTL rats $(P<0.006$ and $P<0.007$, respectively; Table 1). MSG treatment efficiently induced obesity, since the Lee index was higher and retroperitoneal and perigonadal fat pads were larger in MSG rats compared to CTL rats $(P<0.002, P<0.0005$, and $P<0.0001$, respectively; Table 1). Vagotomy did not alter nasoanal length or Lee index, but was effective for decreasing BW and preventing fat deposition in Mvag rats, compared to MSG rats, with reductions of $25 \%$ and $26 \%$ in the retroperitoneal and perigonadal fat stores, respectively $(\mathrm{P}<0.05, \mathrm{P}<0.02$, and $\mathrm{P}<0.05$; Table 1). In addition, the size of the retroperitoneal fat pad was also reduced in Cvag rats, compared to CTL rats $(\mathrm{P}<0.01$; Table 1). To confirm bilateral subdiaphragmatic vagotomy, we analyzed the ratio between stomach weight and BW (14). Cvag rats and Mvag rats presented higher stomach weight per BW ratios $(0.86 \pm 0.05$ and $0.69 \pm$ $0.01 \% \mathrm{BW}$, respectively), compared to CTL rats $(0.49 \pm$ 

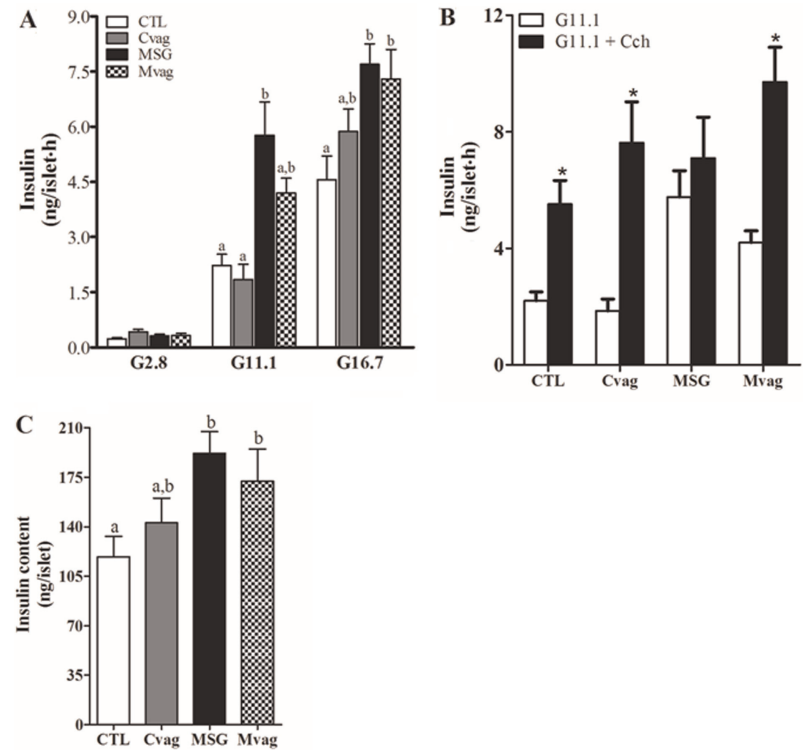

Figure 3. Glucose $(A)$ and carbachol (Cch)-induced insulin secretion $(B)$, and total insulin content $(C)$ of islets from 90 -day-old CTL, Cvag, MSG and Mvag rats. Groups of 4 islets were incubated for $1 \mathrm{~h}$ with increasing glucose $(G)$ concentrations, as indicated in the legend or in the presence of $11.1 \mathrm{mM}$ glucose without or with $100 \mu \mathrm{M}$ Cch. CTL: control; Cvag: CTL with subdiaphragmatic vagotomy; MSG: monosodium glutamate; Mvag: MSG with subdiaphragmatic vagotomy. Data are reported as means \pm SE obtained from 16 groups of islets. Different letters indicate statistically significant differences (two-way ANOVA followed by Duncan's post-test, $P \leq 0.05$ ). ${ }^{*} \mathrm{G} 11.1+$ Cch was different from G11.1 in the same group of islets evaluated (Student's $t$-test; $P \leq 0.05$ ).

$0.01 \% \mathrm{BW} ; \mathrm{P}<0.001)$ and MSG rats $(0.38 \pm 0.08 \% \mathrm{BW}$; $\mathrm{P}<0.001$ ), respectively.

\section{Glucose tolerance and insulin sensitivity}

At the end of the experimental period, all rat groups were submitted to an ipGTT. Before glucose administration, fasted MSG rats did not show any alteration in blood glucose levels, whereas they presented higher plasma insulin levels $(P<0.05$; Figure 2, $A$ and $C)$. After glucose loading, glycemia reached maximal levels at $15 \mathrm{~min}$ in all groups (Figure 2A). MSG rats presented higher glycemia levels at 15 and 60 min of the test, compared with CTL rats $(P<0.006$ and $P=0.05$; Figure $2 A)$. Total glycemia during the ipGTT in MSG rats was $50 \%$ higher than the CTL group $(P<0.006$; Figure 2B). In addition, at $30 \mathrm{~min}$, insulinemia was four-fold higher in MSG rats than in CTL rats $(P<0.0001$; Figure 2C). Vagotomy normalized glucose tolerance and insulinemia, before and at 30 min after the glucose injection, in Mvag rats (Figure 2, A-C). Glucose intolerance in the MSG group was in accordance with an impaired insulin peripheral action, since the HOMA-IR was 3.3-fold higher in $M S G$ rats than in CTL rats $(P<0.0005$; Figure 2D). In addition, the MSG group presented a $37 \%$ reduction in $\mathrm{K}_{\mathrm{ITT}}$, compared with CTL rats $(\mathrm{P}<0.005$; Figure $2 \mathrm{E})$. Vagotomy, performed at 30 days of age, normalized HOMA-IR and $\mathrm{K}_{\mathrm{ITT}}$ values, indicating a significant preventative effect on insulin resistance in adult MSG rats (Figure 2, D and E).

\section{Serum biochemical parameters and lipid content in the liver}

Fasting glucose levels were similar in all groups (Table 2); however, normoglycemia in MSG rats was maintained by hyperinsulinemia, compared to CTL ( $P<0.001$; Table 2). Vagotomy efficiently reduced insulinemia in Mvag rats, with a decrease of $33 \%$ in serum insulin, in comparison with MSG rats $(\mathrm{P}<0.03$; Table 2$)$. The MSG group presented hypertriglyceridemia and hypercholesterolemia $(P<0.0001$ and $P<0.005)$. Serum TG levels were efficiently reduced in Mvag rats compared to MSG rats $(P<0.03$; Table 2$)$. Furthermore, the TG content in the liver of the MSG rats was $57 \%$ higher than in CTL rats $(P<0.02$; Table 2). Early subdiaphragmatic vagotomy normalized the TG content in the liver of adult Mvag rats (Table 2). No alteration was observed in total fat and $\mathrm{CHOL}$ content in the liver.

\section{Islet insulin secretory function and $\mathrm{Ca}^{2+}$ handling}

Figure 3A shows glucose-induced insulin secretion in islets isolated from CTL, Cvag, MSG, and Mvag rats. Insulin release at basal glucose concentration was similar for all groups. At stimulatory glucose concentrations, the insulin release was significantly higher in MSG rat islets compared to $C T L$ rat islets $(P<0.001$ and $P<0.01$, for 11.1 and $16.7 \mathrm{mM}$ glucose, respectively; Figure $3 \mathrm{~A}$ ). This effect was not due to modifications in $\mathrm{Ca}^{2+}$ influx (Figure 4), since the AUC and amplitude of the intracellular $\mathrm{Ca}^{2+}$ concentration $\left(\left[\mathrm{Ca}^{2+}\right] \mathrm{i}\right)$ in MSG rat islets were similar to those of CTL rat islets, when islets were perifused with $16.7 \mathrm{mM}$ glucose (Figure 4, E and $G$ ), whereas the MSG group presented a higher frequency of $\mathrm{Ca}^{2+}$ oscillations than CTL rat islets $(\mathrm{P}<0.0001$; Figure 4F). Vagotomy partially reduced insulin secretion at $11.1 \mathrm{mM}$ glucose in Mvag rats, but did not modify the hormone's secretion at $16.7 \mathrm{mM}$ glucose, compared to MSG rats (Figure $3 \mathrm{~A}$ ). This effect was associated with a lower total $\left[\mathrm{Ca}^{2+}\right] \mathrm{i}$, but a higher number of $\mathrm{Ca}^{2+}$ oscillations in response to $16.7 \mathrm{mM}$ glucose in Mvag rat islets $(P<0.03$ and $\mathrm{P}<0.0001$, respectively; Figure $4, \mathrm{D}-\mathrm{F}$ ).

When the islets were incubated in the presence of $11.1 \mathrm{mM}$ glucose plus $100 \mu \mathrm{M}$ Cch, an M3 receptor agonist (6), MSG rat islets did not present an increase in insulin release (Figure 3B). However, Cch induced a higher intracellular $\mathrm{Ca}^{2+}$ mobilization in the MSG group, since the total quantity and amplitude of $\left[\mathrm{Ca}^{2+}\right] \mathrm{i}$ were enhanced in MSG rat islets compared with $\mathrm{CTL}(\mathrm{P}<0.006$ and $\mathrm{P}<0.02$; Figure 5, $C, E$, and F). Mvag rat islets efficiently enhanced insulin release in response to Cch (Figure 3B), and this effect was accompanied by a normal intracellular $\mathrm{Ca}^{2+}$ mobilization compared with CTL rat islets (Figure 5, D-F). In addition, islet insulin content was $61 \%$ higher in MSG rat islets than in CTL rat islets $(P<0.01$; Figure $3 C)$. Subdiaphragmatic vagal 

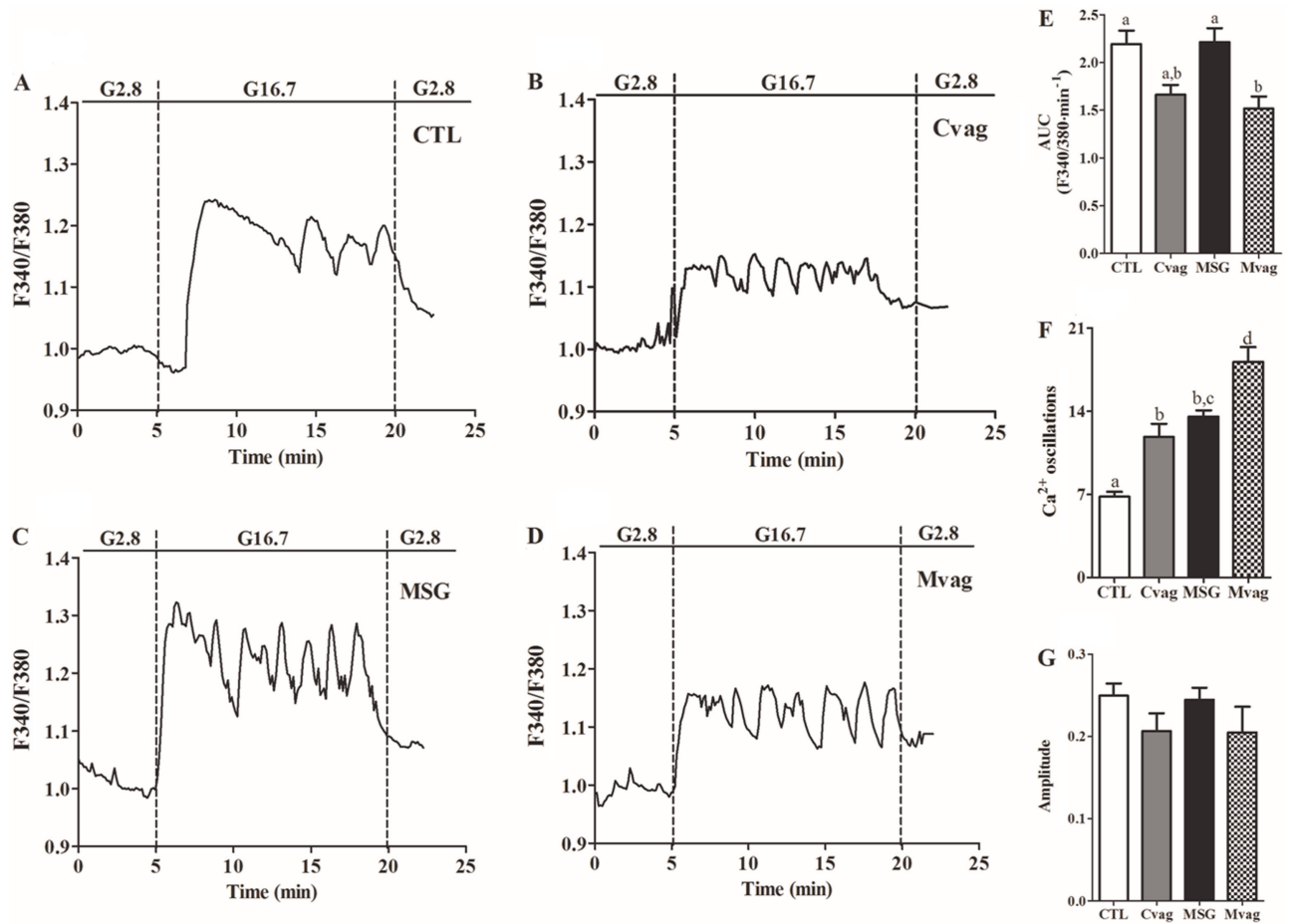

Figure 4. Representative curves of glucose-induced cytoplasmic $\mathrm{Ca}^{2+}$ oscillations in islets isolated from 90 -day-old CTL $(A)$, Cvag $(B)$, MSG $(C)$ and Mvag $(D)$ rats. The area under the curve (AUC) (during G16.7 condition $=5-20 \mathrm{~min})(E)$, frequency of $\mathrm{Ca}^{2+}$ oscillations $(F)$ and amplitude $(G)$ of the $\left[\mathrm{Ca}^{2+}\right] \mathrm{i}$ in response to $16.7 \mathrm{mM}$ glucose. The experiments were performed in a perifusion system in a medium that contained 2.8 or $16.7 \mathrm{mM}$ glucose (G2.8 and G16.7, respectively). The amplitude was calculated by subtracting the highest fluorescence ratio obtained at G16.7 from G2.8 fluorescence values immediately before changing the glucose concentration in the perifusion. Data are the ratio of F340/F380 registered for each group. CTL: control; Cvag: CTL with subdiaphragmatic vagotomy; MSG: monosodium glutamate; Mvag: MSG with subdiaphragmatic vagotomy. Data are reported as means \pm SE that were obtained from 4-14 independent experiments. Different letters represent statistically significant differences (two-way ANOVA followed by Duncan's post-test, $\mathrm{P} \leq 0.05)$.
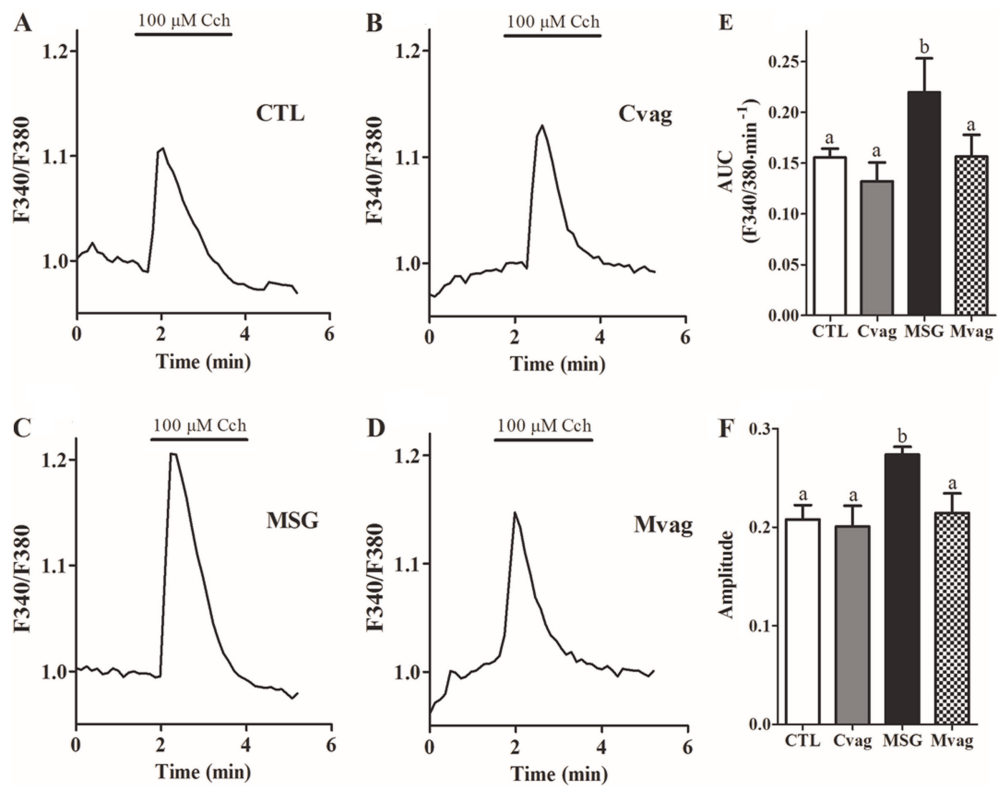

Figure 5. Representative curves of carbachol (Cch) $(100 \mu \mathrm{M})$ induced internal $\mathrm{Ca}^{2+}$ mobilization in islets isolated from 90-day-old CTL $(A)$, Cvag $(B)$, MSG $(C)$ and Mvag $(D)$ rats. E, AUC and $F$, amplitude of the $\left[\mathrm{Ca}^{2+}\right] \mathrm{i}$ in response to Cch. The experiments were performed in a perifusion system in a $\mathrm{Ca}^{2+}$-free medium containing: $11.1 \mathrm{mM}$ glucose (G11.1), $250 \mu \mathrm{M}$ diazoxide, and $10 \mathrm{mM}$ EGTA. Data are the ratio of F340/F380 registered for each group. CTL: control; Cvag: CTL with subdiaphragmatic vagotomy; MSG: monosodium glutamate; Mvag: MSG with subdiaphragmatic vagotomy. Data are reported as means \pm SE obtained from 6-10 independent perifusion experiments. Different letters indicate statistically significant differences (two-way ANOVA followed by Duncan's posttest, $\mathrm{P} \leq 0.05)$. 

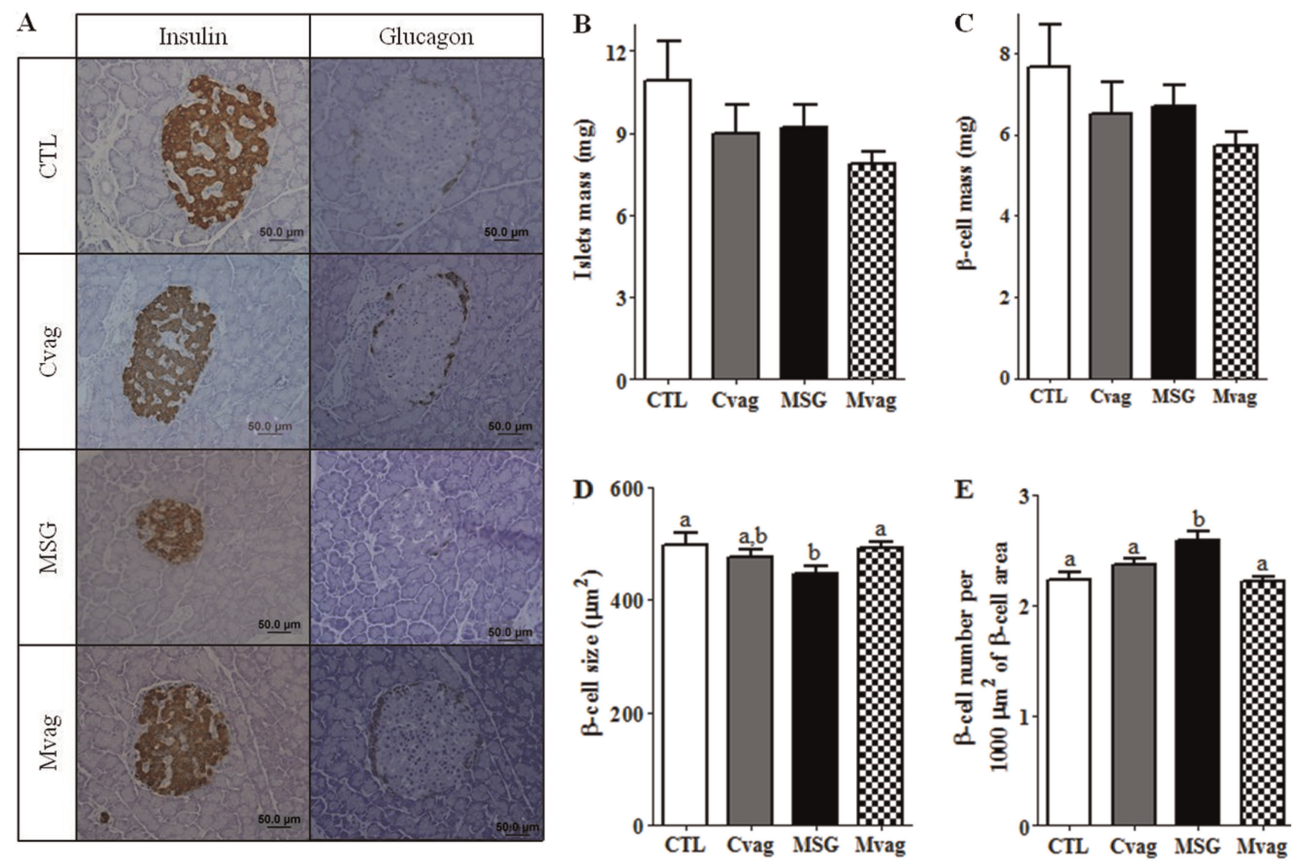

Figure 6. Representative images of pancreas sections stained for insulin or glucagon and hematoxylin $(A)$. Islet mass $(B)$, $\beta$-cell mass $(C), \beta$-cell size $(D)$ and $\beta$-cell number $(E)$ in the pancreas of 90-day-old control $(C T L), C T L$ with subdiaphragmatic vagotomy (Cvag), monosodium glutamate (MSG) and MSG with subdiaphragmatic vagotomy (Mvag) rats. Data are reported as means $\pm S E(n=4)$. Different letters indicate statistically significant differences (two-way ANOVA followed by Duncan's post-test, $\mathrm{P} \leq 0.05$ ).

denervation did not alter islet insulin storage in the Cvag and Mvag groups (Figure 3C).

\section{Pancreatic islet morphology and morphometry}

Figure 6A shows histological pancreatic sections stained for insulin or glucagon. The pancreatic islet architecture was not altered between the groups. Table 3 shows that MSG rats presented reductions of 34 and $49 \%$ in the ratio of pancreas weight per BW and total pancreas area, respectively, compared to $C T L$ rats $(\mathrm{P}<0.0001$ and $\mathrm{P}<0.03)$. After 2 months of subdiaphragmatic vagotomy denervation, Mvag rats presented 1.3- and 1.9-fold increases in pancreas weight and area, respectively, compared with MSG rats
$(\mathrm{P}<0.04$ and $\mathrm{P}<0.03$, respectively; Table 3). Histological analyses showed that pancreatic islets from MSG rats were smaller and had a reduction in $\beta$-cell area without modification in the $\alpha$-cell content, compared with islets from CTL rats $(P<0.0001$; Table 3$)$. Furthermore, the $M S G$ group presented an increase in the percentage of total islet and $\beta$ cell areas per pancreas section analyzed $(P<0.0001)$, with no modification in the distribution of islets by size (Table 3 ). However, no alterations in islet and $\beta$-cell mass were observed (Figure $6, \mathrm{~B}$ and $\mathrm{C}$ ), but an increased $\beta$-cell number/ $1000 \mu \mathrm{m}^{2}$ of $\beta$-cell area was present in the MSG rat pancreas, compared with CTL $(\mathrm{P}<0.04$; Figure $6 \mathrm{E})$. In addition, $\beta$-cell size was lower in the MSG group than in the CTL

Table 1. Final body weight (BW), nasoanal length, Lee Index, retroperitoneal and perigonadal fat pads of 90-day old CTL, Cvag, MSG and Mvag rats.

\begin{tabular}{lcccc}
\hline & CTL & Cvag & MSG & Mvag \\
\hline BW (g) & $361 \pm 11^{\mathrm{a}}$ & $337 \pm 11^{\mathrm{a}, \mathrm{b}}$ & $310 \pm 11^{\mathrm{b}, \mathrm{c}}$ & $277 \pm 11^{\mathrm{c}}$ \\
Nasoanal length (cm) & $24 \pm 0.7^{\mathrm{a}}$ & $25 \pm 0.4^{\mathrm{a}}$ & $22 \pm 0.2^{\mathrm{b}}$ & $22 \pm 0.3^{\mathrm{b}}$ \\
Lee Index & $286 \pm 5^{\mathrm{a}}$ & $278 \pm 4^{\mathrm{a}}$ & $311 \pm 1^{\mathrm{b}}$ & $304 \pm 6^{\mathrm{b}}$ \\
Retroperitoneal fat pads (\% BW) & $0.9 \pm 0.1^{\mathrm{a}}$ & $0.5 \pm 0.1^{\mathrm{b}}$ & $1.6 \pm 0.1^{\mathrm{c}}$ & $1.2 \pm 0.1^{\mathrm{d}}$ \\
Perigonadal fat pads (\% BW) & $0.9 \pm 0.1^{\mathrm{a}}$ & $0.8 \pm 0.04^{\mathrm{a}}$ & $1.9 \pm 0.2^{\mathrm{b}}$ & $1.4 \pm 0.1^{\mathrm{a}}$ \\
\hline
\end{tabular}

Data are reported as means $\pm S E(n=6)$. CTL: control; Cvag: CTL with subdiaphragmatic vagotomy; MSG: monosodium glutamate; Mvag: MSG with subdiaphragmatic vagotomy. Different letters indicate statistically significant differences ( $P \leq 0.05$, two-way ANOVA followed by Duncan's post-test). 
Table 2. Fasting serum glucose, insulin, TG and total $\mathrm{CHOL}$ concentrations and total fat, TG and CHOL content in the liver of 90-dayold CTL, Cvag, MSG and Mvag rats.

\begin{tabular}{lcccc}
\hline & CTL & Cvag & MSG & Mvag \\
\hline Glucose $(\mathrm{mg} / \mathrm{dL})$ & $61 \pm 4$ & $63 \pm 3$ & $69 \pm 3$ & $67 \pm 4$ \\
Serum insulin $(\mathrm{ng} / \mathrm{mL})$ & $0.33 \pm 0.07^{\mathrm{a}}$ & $0.36 \pm 0.07^{\mathrm{a}}$ & $0.79 \pm 0.1^{\mathrm{b}}$ & $0.53 \pm 0.06^{\mathrm{a}}$ \\
Serum TG $(\mathrm{mg} / \mathrm{dL})$ & $126 \pm 5^{\mathrm{a}}$ & $105 \pm 11^{\mathrm{a}}$ & $271 \pm 13^{\mathrm{b}}$ & $224 \pm 26^{\mathrm{c}}$ \\
Serum total CHOL $(\mathrm{mg} / \mathrm{dL})$ & $84 \pm 4^{\mathrm{a}}$ & $81 \pm 4^{\mathrm{a}}$ & $111 \pm 10^{\mathrm{b}}$ & $103 \pm 3^{\mathrm{b}}$ \\
Fat liver content $(\mathrm{mg} / \mathrm{g} \mathrm{liver)}$ & $66 \pm 2$ & $66 \pm 2$ & $77 \pm 5$ & $64 \pm 7$ \\
TG liver content $(\mu \mathrm{g} / \mathrm{mg}$ liver) & $9.3 \pm 0.1^{\mathrm{a}}$ & $8.0 \pm 0.1^{\mathrm{a}}$ & $14.6 \pm 2.2^{\mathrm{b}}$ & $9.8 \pm 1.5^{\mathrm{a}}$ \\
CHOL liver content $(\mu \mathrm{g} / \mathrm{mg}$ liver) & $2.5 \pm 0.2$ & $2.4 \pm 0.2$ & $3.2 \pm 0.3$ & $3.3 \pm 0.6$ \\
\hline
\end{tabular}

Data are reported as means \pm SE $(n=6-11)$. CTL: control; Cvag: CTL with subdiaphragmatic vagotomy; MSG: monosodium glutamate; Mvag: MSG with subdiaphragmatic vagotomy; TG: triglycerides; $\mathrm{CHOL}$ : total cholesterol. Different letters indicate statistically significant differences ( $\mathrm{P} \leq 0.05$, two-way ANOVA followed by Duncan's post-test).

group $(\mathrm{P}<0.02$; Figure 6D). Pancreases of the Mvag rats did not present any alterations in islet and $\beta$-cell areas, compared with MSG rats (Table 3 ). In addition, the percentage of islet and $\beta$-cell areas per pancreas section (Table 3 ), as well as $\beta$-cell number $/ 1000 \mu \mathrm{m}^{2}$ of $\beta$-cell area and $\beta$-cell size per islet, were similar in the pancreases of Mvag and CTL rats (Figure 6, D and E). However, the Mvag group presented a higher islet number per pancreatic section evaluated, compared with the CTL group $(P<0.03$; Table 3 ). Vagotomy, performed at 30 days of age, also reduced the islet and $\beta$-cell areas in the pancreases of 90 -day-old Cvag rats $(P<0.005$ and $P<0.02)$, without altering other islet morphometric parameters (Table 3 and Figure 6).

\section{Discussion}

In the present study, we hypothesized that the increased glucose-induced insulin secretion and hyperinsulinemia in MSG rats may be linked to morphofunctional alterations in the endocrine pancreas due to vagus nerve hyperactivity, since an ANS imbalance with enhanced PNS but decreased SNS action has been previously reported in MSG-induced obesity (10). Therefore, we performed a subdiaphragmatic vagotomy in 30-day-old MSG rats and, after 2 months, adult vagotomized MSG rats exhibited a normalization of some $\beta$ cell morphofunctional alterations and insulinemia, together with the prevention of obesity development and glucose homeostasis disruption.

Islet perifusion experiments demonstrated that enhanced glucose-induced insulin secretion in the MSG group was not accompanied by an alteration in total $\left[\mathrm{Ca}^{2+}\right] \mathrm{i}$ in response to glucose (Figure 4, C and E). However, MSG rat islets did not increase insulin secretion in response to the potentiating agent, Cch (Figure 3B). Previously, we demonstrated a downregulation in the M3/protein kinase $C$ (PKC) pathway in MSG rat islets (18). Here, we extend the data about the M3/PKC mechanism in the MSG islets, showing a higher $\mathrm{Ca}^{2+}$ mobilization from internal stores in response to Cch (Figure 5). It is known that, in $\beta$-cells, Cch increases $\left[\mathrm{Ca}^{2+}\right] \mathrm{i}$ in a biphasic manner. The first phase is induced by

Table 3. Morphometric analysis of the pancreas of 90-day-old CTL, Cvag, MSG and Mvag rats.

\begin{tabular}{lcccc}
\hline & CTL & Cvag & MSG & Mvag \\
\hline Pancreas weight $(\% \mathrm{BW})$ & $0.43 \pm 0.02^{\mathrm{ab}}$ & $0.47 \pm 0.03^{\mathrm{b}}$ & $0.28 \pm 0.02^{\mathrm{c}}$ & $0.36 \pm 0.02^{\mathrm{a}}$ \\
Pancreas area $\left(\mathrm{cm}^{2}\right)$ & $2.56 \pm 0.30^{\mathrm{a}}$ & $3.16 \pm 0.27^{\mathrm{a}}$ & $1.36 \pm 0.11^{\mathrm{b}}$ & $2.63 \pm 0.17^{\mathrm{a}}$ \\
Islet area $\left(\mu \mathrm{m}^{2}\right)$ & $1922 \pm 1044^{\mathrm{a}}$ & $15965 \pm 828^{\mathrm{b}}$ & $13554 \pm 659^{\mathrm{c}}$ & $14674 \pm 646^{\mathrm{b}, \mathrm{c}}$ \\
$\beta$-cell area $\left(\mu \mathrm{m}^{2}\right)$ & $13582 \pm 790^{\mathrm{a}}$ & $11579 \pm 612^{\mathrm{b}}$ & $9859 \pm 476^{\mathrm{c}}$ & $10660 \pm 488^{\mathrm{b}, \mathrm{c}}$ \\
$\alpha$-cell area $\left(\mu \mathrm{m}^{2}\right)$ & $2039 \pm 209$ & $2091 \pm 272$ & $2102 \pm 241$ & $2249 \pm 193$ \\
Total islet area $(\%$ pancreas area) & $0.72 \pm 0.09^{\mathrm{a}}$ & $0.61 \pm 0.06^{\mathrm{a}}$ & $1.09 \pm 0.09^{\mathrm{b}}$ & $0.72 \pm 0.04^{\mathrm{a}}$ \\
Total $\beta$-cell area $(\%$ pancreas area) & $0.51 \pm 0.07^{\mathrm{a}}$ & $0.44 \pm 0.05^{\mathrm{a}}$ & $0.79 \pm 0.05^{\mathrm{b}}$ & $0.53 \pm 0.03^{\mathrm{a}}$ \\
$\%$ small islets $\left(0-5,000 \mu \mathrm{m}^{2}\right)$ & $39.9 \pm 1.9$ & $44.9 \pm 2.7$ & $48.5 \pm 2.6$ & $45.0 \pm 2.6$ \\
$\%$ medium islets $\left(5,000-10,000 \mu \mathrm{m}^{2}\right)$ & $19.0 \pm 2.5$ & $16.1 \pm 1.2$ & $16.0 \pm 1.2$ & $17.2 \pm 1.4$ \\
$\%$ large islets $\left(>10,000 \mu \mathrm{m}^{2}\right)$ & $41.1 \pm 2.6$ & $39.0 \pm 2.5$ & $35.5 \pm 2.2$ & $37.8 \pm 2.3$ \\
Islet number per section & $91 \pm 14^{\mathrm{a}}$ & $118 \pm 9^{\mathrm{a}, \mathrm{b}}$ & $107 \pm 9^{\mathrm{a}, \mathrm{b}}$ & $127 \pm 4^{\mathrm{b}}$ \\
Number of islets analyzed & 832 & 814 & 1091 & 1145 \\
\hline
\end{tabular}

Data are reported as means \pm SE. CTL: control; Cvag: CTL with subdiaphragmatic vagotomy; MSG: monosodium glutamate; Mvag: MSG with subdiaphragmatic vagotomy. Different letters indicate statistically significant differences ( $\mathrm{P} \leq 0.05$, two-way ANOVA followed by Duncan's post-test). 
IP3, and the second phase is due to the opening of $\mathrm{Ca}^{2+}$ channels located on the plasma membrane (25). The increase in $\left[\mathrm{Ca}^{2+}\right] \mathrm{i}$ together with DAG activates PKC, which enhances the efficiency of $\mathrm{Ca}^{2+}$ in insulin granule exocytosis (2). We recently demonstrated a lower PKC content in MSG islets (18). This evidence suggests that a disruption in insulin granule exocytosis occurs in the MSG group, possibly due to PKC, even though the internal $\mathrm{Ca}^{2+}$ flux in response to Cch was adaptively enhanced.

Vagotomy did not alter insulin secretion at $16.7 \mathrm{mM}$ glucose in Mvag rats (Figure 3A) compared to MSG rats. However, a reduction in glucose-induced insulin secretion in islets from MSG rats submitted to early subdiaphragmatic vagotomy has been reported previously (16). In contrast, we found that Cch effectively enhanced insulin secretion in Mvag islets (Figure 3B) and provoked a normal intracellular $\mathrm{Ca}^{2+}$ mobilization (Figure 5). Although further investigations are needed to verify the discrepant results in glucose-induced insulin secretion in the Mvag group, our data indicate that early vagotomy may prevent downregulation in the M3/PKC pathway, which may improve Mvag $\beta$-cell function after a glucose stimulus, because the PLC pathway is also activated in the presence of this molecule in $\beta$-cells (26).

Pancreatic morphometry demonstrated that, although islet and $\beta$-cell mass did not differ between MSG and CTL rat pancreases (Figure 6, B and C), the MSG group presented a higher percentage of total islet and $\beta$-cell areas per pancreas section (Table 3 ), a higher $\beta$-cell number/1000 $\mu \mathrm{m}^{2}$ of $\beta$-cell area (Figure 6E), with reduced $\beta$-cell size (Figure 6D). These islet modifications demonstrate that increased insulin secretion, at stimulatory glucose concentrations (Figure 3A), as well as hyperinsulinemia (Table 2 and Figure $2 \mathrm{C}$ ), are associated with greater numbers of pancreatic $\beta$-cells in MSG islets. Several lines of experimental evidence suggest that the vagus nerve controls cellular proliferation in different tissues in ventromedial hypothalamic lesioned rats $(4,7,27$ 29). This increased proliferation was inhibited by bilateral subdiaphragmatic vagotomy or by administration of the cholinergic blocker, atropine $(4,27)$.

The above studies demonstrated that the vagus nerve is important for the acute control of cellular replication; however, its chronic action has been poorly investigated. Our results indicated that the PNS was chronically involved in endocrine pancreas modification in obesity of MSG rats because, after 2 months of subdiaphragmatic vagotomy, Mvag rats exhibited normal values for pancreas weight and area, percentage of total islet and $\beta$-cell areas (Table 3 ), $\beta$-cell number per $\beta$-cell area, and $\beta$-cell size (Figure 6 ). These data are in accordance with reports demonstrating that early subdiaphragmatic vagotomy decreased $\beta$-cell proliferation in ob/ob mice (5). This evidence supports the hypothesis that vagus nerve hypertonia during the onset of obesity and insulin resistance may program $\beta$-cell number in the pancreas. In addition, we observed that PNS activity was an important determinant of the islet and $\beta$-cell composition in normal rats, since adult Cvag rats presented a decrease in islet and $\beta$-cell areas without any alteration in the mass content of whole pancreas (Figure 6, B and C).

Our study, in addition to detecting morphofunctional alterations in the pancreas of MSG rats, also replicated the obesity parameters that have been previously reported for MSG rats $(13-15,17,30)$, since MSG rats presented lower values for BW and nasoanal length and increased values for Lee index and fat deposition, normoglycemia, hyperinsulinemia, dyslipidemia, glucose intolerance, and insulin resistance (Tables 1 and 2; Figures 1 and 2). Vagotomy, performed at 30 days of age, prevented obesity and improved glucose tolerance and insulin sensitivity in adult Mvag rats (Tables 1 and 2, Figures 1 and 2). We also observed a decrease in retroperitoneal fat deposition in Cvag rats (Table 1). Prevention of body fat accumulation and an improvement in glucose tolerance have been reported in Mvag rats $(14,31)$. It is known that, in the postprandial state, the activation of parasympathetic efferent nerves improves the action of insulin in target tissues $(32,33)$. However, in obesity, PNS hyperactivity occurs, leading to an adaptive enhanced acetylcholinesterase activity $(15,34)$; and this effect may contribute to decreased insulin action and development of type 2 diabetes.

We also demonstrated that Mvag rats presented lower serum TG levels and normal TG content in the liver. It has been accepted that vagal afferent nerves play an important role in energy homeostasis. There have been reports of experimental evidence for the involvement of vagal afferent neurons in the transmission of satiety signals from the gut to the CNS (35). Daly et al. (36) reported that the consumption of an unhealthy diet promotes obesity due to a reduction of gut signals to the CNS, which culminates in increased food intake and increased weight. However, the obesity induced by neonatal treatment with MSG is not linked to a disruption in dietary consumption, but to altered hypothalamic actions that increase PNS activity and decrease the action of the SNS (10), contributing to hyperinsulinemia, obesity and insulin resistance development. As such, the nucleus tractus solitari senses all vagal afferents and contributes to regulate energy balance (35). Furthermore, insulin was reported to enhance the basal activity of duodenal vagal mechanoreceptors, increasing afferent input to the CNS (37); this action in MSG hyperinsulinemic obese rats may enhance PNS activity. In addition, vagal efferent nerves to the liver are involved in insulin-induced hepatic lipogenesis (38). As such, we hypothesized that subdiaphragmatic vagotomy abolishes vagal afferent input to the CNS and efferent input to the liver, which may decrease TG production and, consequently, its levels in the blood serum.

In conclusion, we demonstrated for the first time that hyperinsulinemia and insulin hypersecretion in response to glucose in MSG rats was associated with an increase in $\beta$-cell number promoted by PNS action in pancreatic islets. In contrast, the MSG group presented a diminished islet 
secretory function in the presence of the cholinergic stimulus, which may predispose these rodents to the early development of $\beta$-cell dysfunction. Subdiaphragmatic vagotomy, performed at 30 days of age, prevented islet morphofunctional and whole body nutrient metabolism alterations in adult Mvag rats. It is possible that increased PNS activity in the endocrine pancreas of MSG rats was responsible for the hyperinsulinemia that enhances fat storage, damages glucose homeostasis, and reduces the

\section{References}

1. Plum L, Belgardt BF, Bruning JC. Central insulin action in energy and glucose homeostasis. J Clin Invest 2006; 116: 1761-1766, doi: 10.1172/JCl29063.

2. Gilon $\mathrm{P}$, Henquin JC. Mechanisms and physiological significance of the cholinergic control of pancreatic betacell function. Endocr Rev 2001; 22: 565-604.

3. Ahren B. Islet nerves in focus - defining their neurobiological and clinical role. Diabetologia 2012; 55: 3152-3154, doi: 10.1007/s00125-012-2727-6.

4. Kiba T, Tanaka K, Numata K, Hoshino M, Misugi K, Inoue S. Ventromedial hypothalamic lesion-induced vagal hyperactivity stimulates rat pancreatic cell proliferation. Gastroenterology 1996; 110: 885-893, doi: 10.1053/gast.1996.v110.pm8608899.

5. Edvell A, Lindstrom P. Vagotomy in young obese hyperglycemic mice: effects on syndrome development and islet proliferation. Am J Physiol 1998; 274: E1034-E1039.

6. Yoshimura R, Omori H, Somekawa S, Osaka T, Ito R, Inoue $\mathrm{S}$, et al. Continuous carbachol infusion promotes peripheral cell proliferation and mimics vagus hyperactivity in a rat model of hypothalamic obesity. Biomed Res 2006; 27: 8188, doi: 10.2220/biomedres.27.81.

7. Suzuki $Y$, Inoue $S$, Shimizu $H$, Ishizuka $N$, Kasahara $Y$, Takahashi $\mathrm{T}$, et al. Cell proliferation in visceral organs induced by ventromedial hypothalamic (VMH) lesions: Development of electrical $\mathrm{VMH}$ lesions in mice and resulting pathophysiological profiles. Endocr J 2011; 58: 247-256, doi: 10.1507/ endocrj.K10E-408.

8. Medina A, Yamada S, Hara A, Hamamoto K, Kojima I. Involvement of the parasympathetic nervous system in the initiation of regeneration of pancreatic beta-cells. Endocr $J$ 2013; 60: 687-696, doi: 10.1507/endocri.EJ12-0361.

9. Imai J, Katagiri H, Yamada T, Ishigaki Y, Suzuki T, Kudo H, et al. Regulation of pancreatic beta cell mass by neuronal signals from the liver. Science 2008; 322: 1250-1254, doi: 10.1126/science.1163971.

10. Scomparin DX, Gomes RM, Grassiolli S, Rinaldi W, Martins AG, de Oliveira JC, et al. Autonomic activity and glycemic homeostasis are maintained by precocious and low intensity training exercises in MSG-programmed obese mice. Endocrine 2009; 36: 510-517, doi: 10.1007/s12020-009-9263-2.

11. Stearns AT, Balakrishnan A, Radmanesh A, Ashley SW, Rhoads DB, Tavakkolizadeh A. Relative contributions of afferent vagal fibers to resistance to diet-induced obesity. Dig Dis Sci 2012; 57: 1281-1290, doi: 10.1007/s10620-0111968-4.

12. Olney JW. Glutamate-induced neuronal necrosis in the infant mouse hypothalamus. An electron microscopic study. J Neuropathol Exp Neurol 1971; 30: 75-90, doi: 10.1097/ action of insulin in MSG-induced obesity.

\section{Acknowledgments}

We are grateful to Assis Roberto Escher for animal care and Nicola Conran for editing the English. This study is part of the MSc thesis of C. Lubaczeuski and was supported by grants from Fundação Araucária, CNPq, CAPES, and FAPESP (2011/09012-6).

00005072-197101000-00008.

13. Maiter D, Underwood LE, Martin JB, Koenig JI. Neonatal treatment with monosodium glutamate: effects of prolonged growth hormone $(\mathrm{GH})$-releasing hormone deficiency on pulsatile GH secretion and growth in female rats. Endocrinology 1991; 128: 1100-1106, doi: 10.1210/endo-128-2-1100.

14. Balbo SL, Grassiolli S, Ribeiro RA, Bonfleur ML, Gravena C, Brito $\mathrm{MN}$, et al. Fat storage is partially dependent on vagal activity and insulin secretion of hypothalamic obese rat. Endocrine 2007; 31: 142-148, doi: 10.1007/s12020-0070021-z.

15. Lucinei Balbo S, Gravena C, Bonfleur ML, de Freitas Mathias PC. Insulin secretion and acetylcholinesterase activity in monosodium I-glutamate-induced obese mice. Horm Res 2000; 54: 186-191, doi: 10.1159/000053257.

16. Balbo SL, Bonfleur ML, Carneiro EM, Amaral ME, Filiputti E, Mathias PC. Parasympathetic activity changes insulin response to glucose and neurotransmitters. Diabetes Metab 2002; 28: 3S13-3S17.

17. Nardelli TR, Ribeiro RA, Balbo SL, Vanzela EC, Carneiro EM, Boschero AC, et al. Taurine prevents fat deposition and ameliorates plasma lipid profile in monosodium glutamateobese rats. Amino Acids 2011; 41: 901-908, doi: 10.1007/ s00726-010-0789-7.

18. Ribeiro RA, Balbo SL, Roma LP, Camargo RL, Barella LF, Vanzela EC, et al. Impaired muscarinic type 3 (M3) receptor/PKC and PKA pathways in islets from MSG-obese rats. Mol Biol Rep 2013; 40: 4521-4528, doi: 10.1007/ s11033-013-2546-y.

19. Laye S, Bluthe RM, Kent S, Combe C, Medina C, Parnet P, et al. Subdiaphragmatic vagotomy blocks induction of IL-1 beta mRNA in mice brain in response to peripheral LPS. Am J Physiol 1995; 268: R1327-R1331.

20. Scott AM, Atwater I, Rojas E. A method for the simultaneous measurement of insulin release and $B$ cell membrane potential in single mouse islets of Langerhans. Diabetologia 1981; 21: 470-475, doi: 10.1007/BF00257788.

21. Ng SF, Lin RC, Laybutt DR, Barres R, Owens JA, Morris MJ. Chronic high-fat diet in fathers programs beta-cell dysfunction in female rat offspring. Nature 2010; 467: 963966, doi: 10.1038/nature09491.

22. Bonfleur ML, Vanzela EC, Ribeiro RA, de Gabriel Dorighello $\mathrm{G}$, de França Carvalho $\mathrm{CP}$, Collares-Buzato CB, et al. Primary hypercholesterolaemia impairs glucose homeostasis and insulin secretion in low-density lipoprotein receptor knockout mice independently of high-fat diet and obesity. Biochim Biophys Acta 2010; 1801: 183-190, doi: 10.1016/ j.bbalip.2009.10.012. 
23. Ribeiro RA, Santos-Silva JC, Vettorazzi JF, Cotrim BB, Mobiolli DD, Boschero AC, et al. Taurine supplementation prevents morpho-physiological alterations in high-fat diet mice pancreatic beta-cells. Amino Acids 2012; 43: 17911801, doi: 10.1007/s00726-012-1263-5.

24. Marroqui L, Batista TM, Gonzalez A, Vieira E, Rafacho A, Colleta SJ, et al. Functional and structural adaptations in the pancreatic alpha-cell and changes in glucagon signaling during protein malnutrition. Endocrinology 2012; 153: 16631672, doi: 10.1210/en.2011-1623.

25. Liu YJ, Gylfe E. Store-operated $\mathrm{Ca}^{2+}$ entry in insulinreleasing pancreatic beta-cells. Cell Calcium 1997; 22: 277286, doi: 10.1016/S0143-4160(97)90066-X.

26. Thore S, Wuttke A, Tengholm A. Rapid turnover of phosphatidylinositol-4,5-bisphosphate in insulin-secreting cells mediated by $\mathrm{Ca}^{2+}$ and the ATP-to-ADP ratio. Diabetes 2007; 56: 818-826, doi: 10.2337/db06-0843.

27. Kiba T, Tanaka K, Endo O, Inoue S. Role of vagus nerve in increased DNA synthesis after hypothalamic ventromedial lesions in rat liver. Am J Physiol 1992; 262: G483-G487.

28. Kiba T, Tanaka K, Hoshino M, Numata K, Okano K, Inoue S. Ventromedial hypothalamic lesions induce the proliferation of gastrointestinal mucosal cells in the rat. Life Sci 1995; 57: 827-832, doi: 10.1016/0024-3205(95)02014-A.

29. Kintaka Y, Osaka T, Suzuki Y, Hashiguchi T, Niijima A, Kageyama $\mathrm{H}$, et al. Effects of gastric vagotomy on visceral cell proliferation induced by ventromedial hypothalamic lesions: role of vagal hyperactivity. $J$ Mol Neurosci 2009; 38: 243-249, doi: 10.1007/s12031-009-9200-0.

30. Hirata AE, Andrade IS, Vaskevicius P, Dolnikoff MS. Monosodium glutamate (MSG)-obese rats develop glucose intolerance and insulin resistance to peripheral glucose uptake. Braz J Med Biol Res 1997; 30: 671-674, doi: 10.1590/ S0100-879X1997000500016.

31. Balbo SL, Mathias PC, Bonfleur ML, Alves HF, Siroti FJ, Monteiro OG, et al. Vagotomy reduces obesity in MSG-treated rats. Res Commun Mol Pathol Pharmacol 2000; 108: 291-296.

32. Lautt WW, Macedo MP, Sadri P, Takayama S, Duarte RF, Legare DJ. Hepatic parasympathetic (HISS) control of insulin sensitivity determined by feeding and fasting. Am J Physiol Gastrointest Liver Physiol 2001; 281: G29-G36.

33. Macedo MP, Lima IS, Gaspar JM, Afonso RA, Patarrao RS, Kim YB, et al. Risk of postprandial insulin resistance: the liver/vagus rapport. Rev Endocr Metab Disord 2014; 15: 6777, doi: 10.1007/s11154-013-9281-5.

34. Paes AM, Carniatto SR, Francisco FA, Brito NA, Mathias PC. Acetylcholinesterase activity changes on visceral organs of $\mathrm{VMH}$ lesion-induced obese rats. Int $\mathrm{J}$ Neurosci 2006; 116: 1295-1302, doi: 10.1080/00207450600920910.

35. de Lartigue G, de La Serre CB, Raybould HE. Vagal afferent neurons in high fat diet-induced obesity; intestinal microflora, gut inflammation and cholecystokinin. Physiol Behav 2011; 105: 100-105, doi: 10.1016/j.physbeh.2011.02.040.

36. Daly DM, Park SJ, Valinsky WC, Beyak MJ. Impaired intestinal afferent nerve satiety signalling and vagal afferent excitability in diet induced obesity in the mouse. $J$ Physiol 2011; 589: 2857-2870, doi: 10.1113/jphysiol.2010.204594.

37. Blat $\mathrm{S}$, Malbert $\mathrm{CH}$. Insulin modulates duodenal vagal afferents basal activity. Auton Neurosci 2005; 122: 29-37, doi: 10.1016/j.autneu.2005.07.006.

38. Martin DD, Cincotta AH, Meier AH. Hepatic vagotomy abolishes the circadian rhythm of lipogenic responsiveness to insulin and reduces fat stores in hamsters. Neuroendocrinology 1990; 52: 9-14, doi: 10.1159/000125531. 